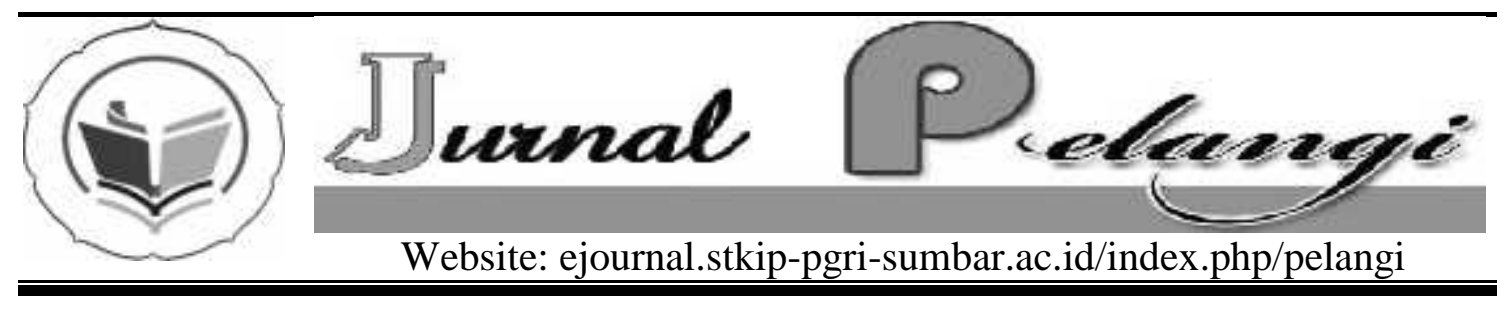

\title{
PENGEMBANGAN HANDOUT PENGAJARAN WRITING II BERBASIS PROCESS GENRE-BASED APPROACH UNTUK MENINGKATKAN KEMAMPUAN MENULIS TEKS DALAM PENULISAN TUGAS AKHIR
}

\author{
Armilia Riza $^{1)}$, Handayani ${ }^{2)}$ \\ ${ }^{1,2)}$ Pendidikan Bahasa Inggris STKIP PGRI Sumatera Barat \\ 1) rizaridwan23@gmail.com \\ ${ }^{2)}$ noviardihandayani@yahoo.co.id
}

INFO ARTIKEL

Diterima : 05/03/2014

Disetujui : 30/05/2014

Kata Kunci:

Writing,

Handout,

Process genre-based approach, Menulis teks

\begin{abstract}
Abstrak
Penelitian ini bertujuan untuk mengembangkan bahan ajar berbasis process genre-based approach. Dalam penelitian ini juga memperkirakan validitas bahan ajar yang dikembangkan. Metode penelitian ini dilakukan dalam empat tahap, yaitu definisi, desain, pengembangan dan penyebaran. Definisi dilakukan untuk menganalisis silabus writing II. Desain dilakukan untuk menganalisis kebutuhan Asse mahasiswa dan dosen. Hasil analisis kebutuhan mahasiswa dan dosen menunjukkan bahwa mereka perlu bahan ajar Pengajaran writing II yang dapat membantu mahasiswa dalam meningkatkan kemampuan menulis teks. Hasil pengembangan menunjukkan validitas produk yang terdapat dalam kategori ini dapat digunakan dengan sedikit perbaikan dengan nilai 75,4. Dapat disimpulkan bahwa produk tersebut dapat digunakan sebagai bahan ajar pengajaran Writing II. Diseminasi dilakukan dalam ujicoba terbatas.
\end{abstract}

Keywords:

Writing,

Handouts,

Process genre-based approach, Written text 
improvement with a value of 75.4. It can be concluded that the product can be used as teaching materials to teach writing. Dissemination was done in limited trial.

\section{PENDAHULUAN}

Mata kuliah Writing II merupakan mata kuliah keahlian yang ditawarkan di perguruan tinggi termasuk di Program Studi Bahasa Inggris STKIP PGRI Sumbar. Mata kuliah lanjutan dari Writing $I$ ini bertujuan untuk melatih mahasiswa mampu menghasilkan beberapa jenis paragraph sederhana seperti recount, narrative, descriptive, procedure, report, dan exposition. Mata kuliah inilah yang akan mengawali penggalian kemampuan mahasiswa untuk melakukan penulisan ilmiah. Kompetensi yang harus dicapai setelah mempelajari mata kuliah ini adalah mahasiswa mampu mengaplikasikan konsep-konsep yang berkaitan dengan struktur organisasi sebuah teks, pengembangan ide tulisan dan ide pendukung sehingga mampu menghasilkan sebuah tulisan dalam bentuk teks. Ketercapaian kompetensi tersebut membutuhkan banyak faktor pendukung, salah satunya adalah bahan ajar.

Berdasarkan berbagai pengamatan yang dilakukan bahan ajar mengajarkan Writing II, didapatkan kesimpulan bahwa mahasiswa hanya diberikan beberapa bahan ajar cetakan yang hanya merupakan kompilasi dari berbagai sumber teori menulis saja hingga hanya mampu memahami mata kuliah Writing II secara teoritikal saja. Bahan ajar seperti ini hanya memberikan pengetahuan tentang teori menulis saja tapi belum mampu membimbing mahasiswa untuk melewati proses menulis itu sendiri. Hal ini tentu bertentangan dengan teori mengembangkan bahan ajar menulis yang disampaikan Gebhard (1996 : 33). Dia menyatakan bahwa that the teacher cannot teach the students to write by looking only at what they have written. The teacher must also understand how it is being came into and why it assumed the form, it did. The teacher has to do some hard things, examine the intangible process, rather than easy thing, and evaluate the tangible product. Maksud dari penyataan ini adalah bahwa pengajar seharusnya tidak mengajarkan skill menulis dari bentuk tulisan yang dihasilkan saja tapi juga harus mampu membuat pelajar menulis melalui proses menghasilkan tulisan itu sendiri.

Hanya fokus terhadap produk tulisan saja tentu berpengaruh pada nilai yang diperoleh oleh mahasiswa dan hasil tulisan mereka. Hasil tulisan mahasiswa cenderung lemah pada pengembangan ide yang menyebabkan sebagian besar mahasiswa mendapat $\mathrm{C}$ dan $\mathrm{D}$ setiap tahun yang membuat mereka mengambil mata kuliah Writing II tahun berikutnya atau mengikuti semester pendek. Pada tahun akademik 2011/2012, lebih dari $50 \%$ mahasiswa yang mendapat nilai $\mathrm{C}$ dan D untuk Writing I dan lebih dari $55 \%$ mahasiswa yang tidak mendapatkan nilai A dan B untuk Writing II (diambil dari data Jurusan Bahasa Inggris Sekolah Tinggi Keguruan Dan Ilmu Pendidikan (STKIP) PGRI Sumatera Barat). Data ini kemudian juga diperkuat dengan wawancara secara informal dengan beberapa dosen Writing dan mahasiswa yang memaparkan bahwa rata-rata 
mahasiswa kesulitan mengembangkan ide tulisan ketika mereka sedang berada pada proses kegiatan menulis itu. Berdasarkan kenyataan ini, jadi bisa disimpulkan bahwa Writing bukanlah hanya sekedar kegiatan menghasilkan tulisan tetapi juga harus memperhatikan bagaimana proses dalam mengembangkan tulisannya. Dosen juga tidak hanya menilai hasil tulisan mahasiswa tapi juga menilai bagaimana mereka berproses.

Handout merupakan bahan ajar berbentuk cetakan yang terdiri dari informasi dari beberapa sumber yang berbeda berkaitan dengan materi ajar. Handout ini juga dijadikan bahan yang diberikan kepada mahasiswa, biasanya dihubungkan dengan pelajaran yang diajarkan atau diprogram dari beberapa macam sumber. Sebuah handout bisa berisi set catatan, tabel, diagram, peta dan materi ilustratif atau ekstensi.

Handout yang akan dikembangkan pada penelitian ini adalah handout yang berbasis pada Process genre - based approach (pendekatan berbasiskan proses dalam menghasilkan genre). Handout ini dikembangkan berbasis tidak hanya kepada produk tulisan yang dihasilkan mahasiswa tapi juga menuntun mereka untuk melalui proses menulis itu sendiri. Handout ini juga akan berisi pertanyaan-pertanyaan yang akan membuka ide mahasiswa dalam penuntunan proses menulis. Dosen hanya akan membimbing dan mengarahkan mahasiswa untuk mengembangkan tulisan yang sesuai dengan kaedah bahasa Inggris dengan memperhatikan struktur teks yang dihasilkan, tata bahasa, isi dan berbagai komponen tulisan. Dengan demikian aktifitas mahasiswa akan meningkat. Selain itu dikarenakan handout juga akan berisi gambar, illustrasi yang didisain semenarik mungkin sehingga melalui visualisasi gambar, mahasiswa bisa memperoleh ide dalam menulis.

Berdasarkan uraian diatas maka diadakan sebuah penelitian yang bertujuan mengembangkan suatu bahan ajar yang disebut dengan handout berbasis Process - genre based approach. Untuk itu dilakukan penelitian dengan judul "Pengembangan Handout Pengajaran Writing II berbasis Process Genre-Based Approach Untuk Meningkakan Kemampuan Menulis Teks pada Program Studi Pendidikan Bahasa Inggris di STKIP PGRI Sumatera Barat dalam Penulisan Tugas Akhir"

Salah satu tujuan penting dari pengajaran menulis di Kurikulum Prodi Bahasa Inggris adalah untuk membuat mahasiswa mampu menghasilkan beberapa genre teks. Itulah sebabnya mengapa menulis biasanya dikatakan sebagai keterampilan yang hanya fokus pada penghasilan produk berupa tulisan. Pernyataan ini bertentangan dengan pendapat Walsh di Kim (2006: 3)) yang menyatakan bahwa prosedur proses penulisan seharusnya peserta didik diberi bantuan untuk mengembangkan cara yang lebih efektif untuk menyampaikan makna dan untuk lebih memahami konten yang ingin mereka ungkapkan. Mereka sangat percaya bahwa peserta didik dapat menemukan apa yang ingin mereka katakan dan kegiatan menulis lebih berhasil melalui model proses dibandingkan dengan pendekatan genre, sebagai pendekatan proses dipandang terpusat pada penulis.

Pendekatan proses juga penting untuk pengajaran menulis, diasumsikan bahwa mengembangkan beberapa genre teks tidak dapat dipisahkan dari proses pembuatan genre itu sendiri. Kombinasi dari kedua pendekatan ini dikenal sebagai PGBA (Process - Genre Based Approach). Badger dan White (2000: 157) menyatakan bahwa model 
pendekatan berbasis proses menghasilkan genre dijelaskan dalam hal pandangan penulisan dan pandangan perkembangan tulisan.

\section{METODE PENELITIAN}

Tahapan penelitian dimulai dengan mengidentifikasi masalah kebutuhan akan bahan ajar di kelas pada mata kuliah Writing II di kelas yang selanjutnya dilakukan analisa kebutuhan terhadap bahan ajar. Analisa ini meliputi analisa silabus dan deskripsi mata kuliah. Selanjutnya penyusunan indikator pembelajaran, yang hasilnya akan dijadikan landasan dalam merancang handout (produk). Handout yang dihasilkan akan divalidasi oleh ahli, untuk mendapatkan kevalidan dan kekonsistenan. Selanjutnya dilakukan uji coba terbatas, tahapan uji coba akan dilanjutkan dengan uji praktikalitas produk untuk melihat apakah handout perlu direvisi atau tidak. Hasil akhir dari tahapan penelitian ini adalah berupa handout berbasis proses-genre.

Dalam penelitian ini, masalah dikaitkan dengan bahan ajar, meskipun tidak semua masalah diselesaikan sekaligus. Analisis Kebutuhan diasumsikan sebagai titik awal untuk mempersiapkan pengembangan bahan ajar untuk memenuhi kebutuhan kurikulum. Hal ini dapat dijelaskan dengan jelas sebagai berikut:

1. Tahapan define: Analisi mukabelakang

Tahap ini dilakukan untuk mendapatkan informasi kondisi riil. Langkah ini dikenal sebagai tahap penilaian kebutuhan. Langkah ini dilakukan melalui tahapan sebagai berikut:

1) Menganalisis silabus mata kuliah Writing II untuk mengetahui apakah materi yang telah diajarkan materi yang sesuai dengan kompetensi umum dan kompetensi khusus

2) Mengulas materi pengajaran Writing II beberapa (buku, lembar kerja mahasiswa), untuk mengetahui cakupan isi materi pengajara, sistem evaluasi dengan kompetensi umum dan kompetensi khusus menulis.

3) Meninjau beberapa literatur tentang PGBA sebagai salah satu bahan pengajaran, untuk mengetahui persiapan dan penerapan handout untuk menulis teks tertulis.

4) Mewawancarai rekan-rekan. Dalam hal ini, peneliti mewawancarai beberapa dosen yang mengajar bahasa Inggris di Prodi Bahasa Inggris STKIP PGRI Sumbar dalam rangka untuk mengumpulkan informasi tentang penerapan pengajaran Writing II dan bahan ajar menulis yang digunakan. Hal itu dilakukan untuk mendapatkan informasi apa yang mereka pikirkan tentang bahan ajar yang tersedia apakah bahan ajar telah sesuai permintaan kurikulum.

5) Menganalisis karakteristik mahasiswa sebagai patokan lain pengembangan bahan ajar. Hal itu dilakukan untuk membuat bahan ajar yang akan yang dilakukan dipahami dengan mudah oleh mahasiswa.

\section{Tahapan Design}

Tahapan ini dilakukan dengan menentukan indicator-indikator yang akan dijadikan pedoman dalam pengembangan produk. Perancangan produk ini dilakukan berdasarkan hasil analisa silabus dan kebutuhan mahasiswa. Langkah yang dilakukan yaitu dengan menentukan konsep menulis berbasiskan proses dan menulis berbasiskan produk (genre) yang kemudian dikaitkan dengan teori jenisjenis teks. Selanjutnya adalah untuk memeriksa teori tentang perkembangan 
handout berbasis PGBA yang dikembangkan. Setelah menguasai teori terkait dengan PGBA, peneliti kemudian bekerja untuk mengembangkan rancangan itu didasarkan pada teori-teori yang relevan yang telah dipelajari.

\section{Tahap develop (pengembangan)}

Pada tahapan ini akan dilakukan tindakan memvalidasi, menguji konsistensi dan praktikalitas dari handout berbasis PGBA.

\section{a. Tahap validasi}

Setelah draft itu telah dirancang, draft harus ditinjau berulang kali oleh peneliti atau dibantu oleh rekan-rekan (peer review). Selanjutnya setelah handout telah disusun, itu divalidasi oleh ahli. Para ahli hanya memvalidasi validasi konstruk karena draft adalah instrumen non tes. Seperti dijelaskan oleh Sugiyono (2008: 33), alat uji non tes dapat divalidasi hanya oleh validitas konstruk. Kemudian, peneliti juga membahas prototipe dengan empat praktisi, mereka adalah dosen bahasa Inggris atau rekan kerja. Pendapat dari para ahli akan digunakan sebagai dasar untuk penyelesaian dan revisi dari handout. Adapun aspek-aspek yang divalidasi dapat dilihat pada Tabel 1 .

Tabel 1. Aspek Validasi

\begin{tabular}{|c|c|c|c|}
\hline No & Aspek & Metode pengumpulan data & Instrumen \\
\hline 1 & Kelayakan isi & Memberikan lembar validasi & Lembar validasi \\
\hline 2 & Kebahasaan & kepada pakar Writing pakar & \\
\hline 3 & Sajian & media/pengembangan & \\
\hline 4 & Kegrafisan & kurikulum dan pakar bahasa & \\
\hline
\end{tabular}

Tabel 2. Aspek Praktikalitas

\begin{tabular}{lllll}
\hline No & Aspek & Metode pengumpulan data & Instrumen \\
\hline 1 & Kemudahan penggunaan & $\begin{array}{l}\text { Angket pada dosen dan } \\
\text { mahasiswa }\end{array}$ & $\begin{array}{l}\text { Lembar } \\
\text { angket }\end{array}$ \\
2 & Waktu dan biaya & Wawancara dengan beberapa & $\begin{array}{l}\text { Pedoman } \\
3\end{array}$ & $\begin{array}{l}\text { Interpretasi/pemahaman } \\
\text { dosen dan mahasiswa }\end{array}$ \\
4 & Keberfungsian & wawancara \\
\hline
\end{tabular}

b. Tahap pengujian konsistensi

Tahap pengujian konsistensi dilakukan setelah validasi selesai. Para peneliti mengumpulkan dan menghitung data dari pakar terhadap handout. Tahap konsistensi dilakukan dengan berdasarkan pada data yang telah diberikan oleh pakar. Validasi akan dilakukan minimal dua kali untuk melihat sejauh mana tingkat konsistensi dari handout yang telah divalidasi pakar. Pengambilan data akan dilakukan selang dua minggu setelah pengambilan data pertama diambil untuk menghilangkan invalid data jika data diambil terlalu dekat dengan pengambilan pertama atau terlalu jauh.

c. Tahap Uji coba produk

Setelah draft direvisi berdasarkan masukan dari para ahli, langkah selanjutnya dilakukan uji coba terbatas terhadap handout. Hal ini dilakukan dengan memberikan uji coba pada produk yang sudah divalidasi. Uji coba akan dilakukan secara terbatas dengan satu lokal saja Program studi Pendidikan Bahasa Inggris STKIP-PGRI Sumbar. Data dari hasil uji coba ini akan dijadikan sebagai dasar dalam merevisi 
produk, sehingga produk yang dihasilkan benar-benar layak digunakan didalam proses perkuliahan.

\section{d. Tahap praktikalitas}

Tahap praktikalitas adalah tahap yang akan dilalui berikutnya untuk melihat sejauh mana keterpakaian handout sebagai bahan ajar. Hal ini dilakukan dengan memberikan uji coba pada produk yang sudah divalidasi. Uji praktikalitas akan dilakukan dengan pengambilan data melalui angket dan wawancara dengan beberapa dosen dan mahasiswa yang menggunakan handout sebagai bahan ajar. Adapun aspek-aspek praktikalitas Handout dapat dilihat pada Tabel 2.

Setelah ujicoba dilakukan, akan dilakukan analisa lanjut. Jika handout dikatakan belum valid, konsisten dan praktis maka tahap revisi kedua akan dilakukan untuk memperbaiki bagian yang masih dianggap kurang. Hasil revisi akan dijadikan pedoman untuk perbaikan Handout yang telah dikembangnkan. Hasil revisi akan menjadi hasil akhir pengembangan handout berbasis PGBA.

4. Tahap disseminate (penyebaran)

Tahap desiminasi (penyebaran) dilakukan secara terbatas pada skala kecil dalam penelitian ini. Data penelitian dikumpulkan dengan dua cara, data kuantitatif dan data kualitatif. Data kuantitatif dikumpulkan untuk mengetahui analisis kebutuhan, validasi pakar dan kepraktisan produk. Hal itu dilakukan untuk mengetahui apa jenis bahan pengajaran yang dibutuhkan, bagaimana tingkatan validitas dan kepraktisan dari prototipe bahan ajar yang. Data kuantitatif berarti data akan disajikan dalam bentuk laporan numerik dan akan disajikan dalam bentuk persentase, grafik matriks, dan. Data kuantitatif diambil dengan menggunakan checklist validasi ceklist dan kuesioner.
Data kualitatif diambil dengan menggunakan wawancara. Wawancara dilakukan untuk mendukung data dari kuesioner analisis kebutuhan. Di sini peneliti mewawancarai beberapa mahasiswa dengan kemampuan yang berbeda. Data diambil dari skor rekaman peneliti, karena peneliti adalah dosen di kelas. Untuk mendukung data dari dosen, wawancara peneliti dosen yang mengajar Writing II.

Selanjutnya untuk mengetahui hasil belajar mahasiswa akan dilakukan tes menulis. Tes akan diberikan dengan meminta mahasiswa memilih salah satu dari beberapa topik untuk dikembangkan menjadi tulisan. Data akan dianalisa dalam bentuk kuantitatif yang selanjutnya akan dijabarkan dalam analisa kulalitatif. Teknik-teknik dan instrumen digambarkan pada Tabel 3.

Disebutkan bahwa data penelitian terdiri dari data kuantitatif dan kualitatif. Data dianalisis pada teknik yang berbeda. Analisis data merupakan salah satu dari serangkaian kegiatan penelitian ini, sehingga kegiatan ini adalah untuk menganalisis data yang terkait dengan rangkaian kegiatan sebelumnya mulai dari jenis yang dipilih penilaian, rumusan masalah dan tujuan penelitian, jenis data, jumlah subyek uji coba, serta asumsi yang mendasari kegiatan penelitian teoritis. Teknik yang berbeda akan digunakan untuk menganalisis data yang berbeda. Sebelum instrumen digunakan, harus diuji untuk membuat data yang diperoleh lebih baik dan mencapai target. Hal-hal yang akan di penentuan instrumen, yaitu:

a. Analisa kebutuhan

Karena peneliti memulai penelitian ini didasarkan pada kebutuhan mahasiswa untuk belajar materi, peneliti akan menganalisis data berdasarkan skala Likert. Hasilnya akan dianalisis dengan mencari persentase setiap pernyataan untuk setiap pilihan jawaban, 
dengan menggunakan rumus sebagai berikut:

$$
P=\frac{f}{n} x 100 \%
$$

Catatan:

$\mathrm{P}=$ persentase

$\mathrm{f}=$ frekuensi penjawab

$\mathrm{n}=$ jumlah responden
Mengenai analisis data kuesioner, Ward (2006) mengungkapkan bahwa data yang telah persentase kemudian ditentukan persentase kuesioner keseluruhan dengan mengelompok-kan data berdasarkan jenis pernyataan, pernyataan positif dan negatif, maka hasil diinterpretasikan dengan kategori penggunaan berdasarkan persentase seperti pada Tabel 4.

Tabel 3.Teknik pengumpulan data penelitian

\begin{tabular}{llll}
\hline No & \multicolumn{1}{c}{ Aspek } & Tehnik pengumpulan data & \multicolumn{1}{c}{ Instrumen } \\
\hline 1 & Analisa kebutuhan & Angket, Wawancara & Lembaran angket \\
2 & Validitas & Lembar validasi pakar & Pedoman wawancara \\
3 & Praktikalitas & Angket & Lembaran angket \\
\hline
\end{tabular}

Tabel 4. Kriteria Analisa Kebutuhan

\begin{aligned} & \hline $\mathrm{P} \% \multicolumn{1}{c}{$ Kriteria } \\ & \hline $\mathrm{P}=0$ Tidak satupun responden \\ & $1<\mathrm{P}<25$ Beberapa responden \\ & $25<\mathrm{P}<50$ Sebagian besar responden \\ & $\mathrm{P}=50$ Setengah dari jumlah responden \\ & $50<\mathrm{P}<75$ Lebih dari setengan jumlah responden \\ & $75<\mathrm{P}<100$ Hampir semua responden \\ & $\mathrm{P}=100$ Semua responden \\ & \hline\end{aligned}

(Riduwan: 2005)

Tabel 5. Persentase Kriteria Kebutuhan

\begin{tabular}{ccc}
\hline No & Persentase kebutuhan $(\%)$ & Kriteria kebutuhan \\
\hline 1 & $0-20$ & Sangat tinggi \\
2 & $21-40$ & Tinggi \\
3 & $41-60$ & Sedang \\
4 & $61-80$ & Rendah \\
5 & $81-100$ & Sangat rendah \\
\hline
\end{tabular}

(Riduwan: 2005)

Tabel 6. Validasi Produk

\begin{tabular}{ccc}
\hline No & Rentang nilai & kategori \\
\hline 1 & $0-20$ & Tidak valid \\
2 & $21-40$ & Kurang Valid \\
3 & $41-60$ & Cukup valid \\
4 & $61-80$ & Valid \\
5 & $81-100$ & Sangat valid \\
\hline
\end{tabular}


Berdasarkan persentase jumlah responden, kriteria akan kebutuhan bahan ajar bisa dilihat pada Tabel 5 . Kriteria dari analisis kebutuhan dapat dijelaskan bahwa persentase jumlah dan kriteria proporsional secara terbalik. Jika persentase kebutuhan rendah maka permintaan tinggi. Begitupun sebaliknya. Untuk menguji kriteria kebutuhan, diferensial semantik digunakan. Jika hasilnya sangat rendah, itu berarti bahwa kebutuhan produk akan tinggi.

b. Validasi pakar

Hasil validasi dari pakar terhadap seluruh aspek yang dinilai disajikan dalam bentuk tabel. Selanjutnya rerata skor akan dicari dengan menggunakan rumus:

Validity score $=\frac{\sum \text { scoreperitem }}{\text { Maxscore }}$

Untuk menentukan tingkat kevalidan Handout digunakan kriteria seperti pada Tabel 6 .

\section{HASIL DAN PEMBAHASAN}

Pada analysis muka belakang, peneliti melakukan observasi pada kelas sebelum produk dihasilkan untuk mengetahui apa yang dibutuhkan dosen dan mahasiswa sebagai bahan ajar menulis. Peneliti memberikan angket kepada dosen dan mahasiswa bagaimana pendapat mereka tentang mata kuliah menulis sebagai salah satu mata kuliah wajib pada program studi bahasa Inggris, bahan ajar yang selama ini digunakan dan bahan ajar seperti apa yang dibutuhkan.

Berdasarkan kurikulum yang digunakan di STKIP PGRI Sumbar, tuntutan kurikulum mata kuliah Writing II merupakan mata kuliah lanjutan dari Writing I, yang melatih mahasiswa untuk menulis beberapa jenis teks sederhana seperti recount, narrative, descriptive, procedures, report, dan exposition. Tujuan khusus dari kurikulum ini meminta siswa untuk dapat menghasilkan beberapa jenis teks tertulis yang benar dalam struktur, penggunaan bahasa dan tata bahasa. Didalam proses menulis diharapkan dosen mampu membimbing siswa dalam proses menulis dikarenakan menulis tidak dapat dipisahkan dari proses menghasilkan tulisan itu sendiri. Hasil dari analisa kurikulum menunjukkan bahwa tujuan umum dalam mata kuliah Writing II adalah mahasiswa mampu untuk mengungkapkan ide dalam bentuk tulisan dalam konteks interpersonal tertentu baik formal ataupun informal sampai menghasilkan sebuah teks tertulis. Selanjutnya tujuan khusus dalam mata kuliah ini meminta mahasiswa untuk dapat mengungkapkan makna dan langkah retorika dalam menghasilkan teks tertulis yang mencakup aspek menentukan topik, menuliskan ide pokok, menggunakan tata bahasa yang benar secara struktur, membuat kerangka karangan, melakukan proses editing dan revisi sampai kemudian menghasilkan sebuah teks.

Bahan ajar mata kuliah Writing II yang biasa dipakai selama ini merupakan kompilasi dari berbagai sumber buku yang ditulis oleh beberapa ahli yang hanya membicarakan menghasilkan teks secara teoritikal belum bisa memenuhi kebutuhan akan bahan ajar yang membantu siswa berproses dalam menghasilkan sebuah tulisan terutama dalam melibatkan siswa dalam berbagi informasi dalam menghasilkan tulisan. Bahan ajar yang digunakan juga belum berisikan panduan-panduan bagi mahasiswa untuk menghasilkan kerangka karangan, melakukan editing dan revisi. Bahkan dalam berproses mahasiswa biasanya bekerja dalam buku yang terpisah dengan bahan ajar. Dari fakta yang 
ditemukan diatas bisa diasumsikan bahwa aktifitas menghasilkan tulisan hanya berpusat pada bagaimana menghasilkan tulisan tapi mengabaikan proses dalam menghasilkan tulisan. Hal ini sangat bertentangan dengan pernyataan Gebhard (1996: 31) yang menyatakan bahwa pengajar tidak bisa mengajarkan siswa menulis hanya dari apa yang mereka tulis. Pengajar harus bisa memahami dan membimbing bagaimana ide yang dituangkan tadi bisa muncul dan mengapa bisa muncul.

Sebelum handout dihasilkan, peneliti mereview berbagai sumber bacaan untuk mendapatkan gambaran bahan ajar seperti apa yang cocok untuk membantu mahasiswa dalam mengembangkan ide mereka dalam proses menulis. Pendekatan yang dipilih dan tepat dalam membantu mahasiswa berproses dalam menghasilkan tulisan adalah Proses genre - based approach (pendekatan berbasiskan proses dalam menghasilkan genre teks). Selanjutnya bahan ajar yang dihasilkan berupa bahan ajar cetak dalam bentuk handout yang tidak hanya berisi penjelasan tentang teks secara teori, tapi juga berisikan aktifitas-aktifitas yang membimbing mahasiswa dalam proses menghasilkan tulisan serta ditambah halaman kosong sebagai media bagi mahasiswa bekerja.

Peneliti melakukan beberapa kegiatan untuk menganalisis kebutuhan akan bahan ajar dari beberapa orang dosen yang pernah mengampu mata kuliah Writing II. Seperti disebutkan sebelumnya, penilaian kebutuhan itu diambil dari hasil angket dan informal wawancara. Wawancara dilakukan dengan bertatap muka dengan beberapa orang dosen tentang pengalaman mereka dalam mengajar mata kuliah Writing II, pengalaman dosen dalam mempersiapkan materi pengajaran mata kuliah Writing II, pengalaman dosen dalam mengajar mata kuliah Writing II dan persepsi mereka tentang bahan ajar yang biasa digunakan. Selanjutnya, peneliti juga membagikan angket untuk dosen yang pernah mengampu mata kuliah Writing II yang memiliki indikator yang sama dengan item dalam wawancara. Angket diberikan pada 3 orang dosen. Dari angket, peneliti mendapat gambaran umum tentang pendapat dosen untuk bahan pengajaran menulis. Kuesioner untuk penilaian kebutuhan dosen yang disusun berdasarkan kisi-kisi analisa kebutuhan bahan ajar mata kuliah Writing II.

Berdasarkan data pada Tabel 7, distribusi jawaban dosen dianggap dari empat indikator. Indikator pertama adalah pengalaman dosen pada pengajaran Writing II. Persentase indikator ini adalah 71.66. Dari data dapat dilihat bahwa hampir semua responden memiliki pengalaman yang baik dalam mengajar bahasa Inggris. Indikator kedua adalah pengalaman dosen dalam mempersiapkan bahan ajar pada mata kuliah Writing II. Persentase indikator ini adalah 72.22. Data di atas menunjukkan bahwa hampir semua responden menyiapkan bahan ajar sebelum mereka menjalankan proses pengajaran mata kuliah Writing II . Indikator ketiga pengalaman mengajar dosen dalam mengajar mata kuliah Writing II .

Berdasarkan data pada Tabel 7, indikator pengalaman dosen dalam mengajar pada mata kuliah Writing II adalah 48,15. Hal ini dapat diasumsikan bahwa lebih dari separuh responden tidak membimbing mahasiswa untuk melakukan proses dalam menghasilkan tulisan. Indikator terakhir adalah 40 . Dari data tersebut, dapat disimpulkan bahwa sebagian besar responden tidak mempersiapkan pengajaran menulis teks yang berbasis pada pendekatan proses menghasilkan tulisan. 
Berdasarkan data pada Tabel 7 dapat disimpulkan bahwa dosen memiliki pengalaman yang baik dalam mengajar mata kuliah Writing II. Dalam persiapan bahan ajar untuk mata kuliah Writing II dosen mempersiapkan bahan ajar yang cukup sebagai bahan ajar mata kuliah Writing II tetapi bahan ajar yang diberikan belum mampu membimbing mahasiswa dalam melewati proses menghasilkan tulisan. Dapat disimpulkan bahwa bahan ajar yang selama ini digunakan hanya mampu membuat mahasiswa menghasilkan tulisan tapi belum bisa membimbing dalam proses menghasilkan tulisan. Bisa disimpulkan bahwa dosen membutuhkan bahan ajar yang mampu membimbing mereka dalam proses menulis genre.

Untuk mendapatkan data tentang persepsi dan kebutuhan mahasiswa pada bahan ajar untuk mata kuliah Writing II, peneliti menyebarkan angket pada 32 mahasiswa program studi bahasa Inggris STKIP PGRI Sumbar. Dari angket didapatkan gambaran tentang kebutuhan mahasiswa yang dirancang sesuai dengan indicator analisa kebutuhan bahan ajar. Angket yang dibagikan disusun berdasarkan indicator persepsi mahasiswa terhadap mata kuliah Writing II, pengalaman mahasiswa dalam kegiatan pembelajaran mata kuliah Writing II dan persepsi mereka tentang bahan ajar mata kuliah Writing II yang selama ini digunakan.

Berdasarkan data pada Tabel 8, dapat dijelaskan bahwa analisa kebutuhan bahan ajar mahasiswa dirumuskan dalam tiga indikator. Indicator pertama adalah persepsi mahasiswa tentan mata kuliah Writing II. Berdasarkan berbagai indicator yang dikembangkan dapat dianalisa bahwa mahasiswa memiliki persepsi yang cukup baik pada mata kuliah Writing II. Skor menunjukkan pada poin 71.68 yang dikategorikan cukup baik. Dapat disimpulkan bahwa sebagian besar responden memiliki persepsi yang cukup baik pada mata kuliah Writing II. Indikator kedua adalah pengalaman belajar mahasiswa pada mata kuliah Writing II. Berdasarkan berbagai indicator yang dikembangkan dapat dianalisa bahwa mahasiswa memiliki pengalaman yang kurang baik pada mata kuliah Writing II. Skor menunjukkan pada poin 64.77 yang dikategorikan kurang baik. Dapat disimpulkan bahwa sebagian besar responden memiliki pengalaman yang kurang baik pada mata kuliah Writing II. Berdasarkan proses dalam menulis, mahasiswa berpendapat bahwa pembelajaran Writing II belum membimbing mereka berproses dalam menghasilkan tulisan. Indikator ketiga adalah persepsi mahasiswa terhadap bahan ajar yang biasa digunakan pada mata kuliah Writing II.

Berdasarkan berbagai indicator yang dikembangkan dapat dianalisa bahwa mahasiswa memiliki pendapat yang tidak baik pada bahan ajar yang biasa digunakan pada mata kuliah Writing II. Skor menunjukkan pada poin 58.07 yang dikategorikan tidak baik. Dapat disimpulkan bahwa sebagian besar responden memiliki pendapat yang tidak baik pada bahan ajar pada mata kuliah Writing II. Berdasarkan berbagai indicator yang dikembangkan berdasarkan proses dalam menulis, mahasiswa berpendapat bahwa bahan ajar yang biasa digunakan pada mata kuliah Writing II tidak membimbing mereka berproses dalam menghasilkan tulisan. 
Tabel 7. Analisa Kebutuhan Dosen

\begin{tabular}{llc}
\hline No & \multicolumn{1}{c}{ Indikator } & \multicolumn{1}{c}{ Score } \\
\hline 1 & Pengalaman Dosen dalam mengajar mata kuliah Writing II & 71,66 \\
2 & $\begin{array}{l}\text { Pengalaman dosen dalam mempersiapkan bahan ajar pada mata } \\
\text { kuliah Writing II }\end{array}$ & 72,22 \\
3 & $\begin{array}{l}\text { Pengalaman dosen dalam mengajar pada mata kuliah Writing II } \\
\text { Persepsi Dosen pada bahan ajar mata kuliah Writing II yang } \\
\text { tersedia }\end{array}$ & 40,15 \\
\hline
\end{tabular}

Tabel 8. Analisa Kebutuhan Mahasiswa

\begin{tabular}{llc}
\hline No & \multicolumn{1}{c}{ Indikator } & \multicolumn{1}{c}{ Score } \\
\hline 1 & Persepsi mahasiswa terhadap mata kuliah Writing II & 71.68 \\
2 & $\begin{array}{l}\text { Pengalaman belajar mahasiswa dalam mata kuliah Writing } \\
\text { II }\end{array}$ & 64.77 \\
3 & $\begin{array}{l}\text { Persepsi mahasiswa terhadap bahan ajar yang biasa } \\
\text { digunakan dalam mata kuliah Writing II }\end{array}$ & 58.07 \\
\hline
\end{tabular}

Berdasarkan data pada Tabel 8, dapat disimpulkan bahwa mahasiswa membutuhkan bahan ajar yang mampu membimbing mereka dalam proses menulis terutama dalam melewati proses menulis, dari memilih topic, membuat kerangka karangan, melakukan editing, revisi dan menghasilkan tulisan. Data diatas juga dapat membantu peneliti dalam menentukan bahan ajar seperti apa yang akan dikembangkan. Bahan ajar dalam bentuk handout yang akan dikembangkan berbasiskan proses dalam menghasilkan genre, yang bertujuan membantu mahasiswa dalam melewati proses kegiatan menghasilkan tulisan.

Tahapan ini dimulai dengan memperhatikan tujuan umum pembelajaran mata kuliah Writing II berdasarkan kurikulum program studi bahasa Inggris yang tertera dalam buku panduan akademik yakni "Melatih mahasiswa untuk menulis beberapa jenis teks sederhana seperti recount, narrative, descriptive, procedures, report, dan exposition.". dari tujuan umum ini dapat ditarik kesimpulan bahwa pembelajaran Writing II melatih siswa untuk dapat menghasilkan sebuah tulisan dengan genre tertentu.

Selanjutnya dipelajari beberapa referensi untuk menjadi landasan bahan ajar berbentuk handout seperti apa yang akan dikembangkan. Dari hasil analisa kebutuhan yang dihasilkan mahasiswa membutuhkan tuntunan dalam proses mengembangkan ide mereka dalam menghasilkan tulisan. Berdasarkan hasil analisa maka pendekatan yang paling bisa digunakan adalah pendekatan dengan berbasiskan proses dalam menghasilkan tulisan yang berbentuk gen)re (Proses genre - based approach). Pendekatan ini terdiri dari berbagai tahapan yakni

Handout ini dikembangkan dengan berbasiskan Process genre-based approach (pendekatan berbasis proses dalam menghasilkan genre teks), maka handout ini berisikan step-step proses menulis yakni providing information yakni bagian yang membangkitkan kemampuan mahasiswa dalam memahami teks yang akan dihasilkan. Kemudian dilanjutkan dengan tahapan Modelling yang berisikan contoh teks yang akan 
dihasilkan nantinya dengan memberikan paparan tentang struktur teks. Selanjutnya Considering genre, pada bagian ini aktifitas yang akan dilakukan mahasiswa adalah memahami lexicogrammatical yang akan membangun teks yang akan dihasilkan. Tahapan selanjutnya adalah Planning yakni berisikan aktifitas dimana mahasiswa merancang topic yang akan dikembangkan. Joint construction adalah tahapan selanjutnya yang berisikan aktifitas diskusi kelas, dimana mahasiswa akan diundang untuk berbagi ide yang sudah mereka rancang pada tahapan sebelumnya tentang teks yang akan dihasilkan. Tahapan ini dilanjutkan dengan Independent construction yang berisikan aktifitas dimana mahsiswa secara individu akan mengembangkan rancangan yang sudah didiskusikan bersama-sama sesuai dengan pemikiran mereka sendiri-sendiri. Bagian terakhir adalah Revising dimana mahasiswa akan saling menilai dan merevisi hasil kerja mereka.

Validasi handout dilakukan oleh seorang validator yang ahli dalam pengembangan dan aplikasi bahan ajar yang berbasis PGBA pada pembelajaran menulis. Hasil validasi divalidasi berdasarkan empat aspek yakni yang pertama konten, aspek kebahasaan, presentasi dan tampilan. Berdasarkan data pada Tabel 9 dapat dijelaskan secara rinci sebagai berikut.

1) Konten

Penilaian pada konten berisikan beberapa komponen yakni bahwa handout yang telah dirancang terkategori baik dengan nilai rata-rata 71.15 untuk semua hanout. Handout ini berarti telah cukup baik dalam pengembangan jika disesuaikan dengan tujuan umum dan tujuan khusus pembelajaran Writing II. Handout ini juga cukup baik dalam memaparkan teori dan pelatihan untuk teks yang akan dihasilkan oelh mahasiswa.

2) Bahasa

Penilaian akan kebahasaan yang digunakan berkategori baik dengan nilai rata-rata 81.25 untuk semua handout. Pada bagian ini yang dinilai adalah tata bahasa yang digunakan serta pemilihan bahasa yang digunakan yang disesuaikan dengan level mahasiswa.

\section{Tabel 9. Hasil validasi handout}

\begin{tabular}{|l|l|l|l|}
\hline No & Aspek & Skor & Total skor \\
\hline 1 & Kontent & 37 & 71.15 \\
\hline 2 & Bahasa & 13 & 81.25 \\
\hline 3 & Sajian & 12 & 71.75 \\
\hline 4 & Tampilan & 18 & 73 \\
\hline Rata-rata & 75.4 \\
\hline
\end{tabular}

\section{3) Sajian}

Penilaian akan sajian yang dberikan berkategori baik dengan nilai rata-rata 71.75 untuk semua handout. Pada bagian ini dinilai bagaimana handout ini disajikan sesuai dengan kaidah handout yang menyediakan halaman kosong untuk media mengembnagkan aktifitas menulis.

\section{4) Tampilan}

Tampilan handout ini dikategorikan baik dengan nilai rata-rata 73 yang berarti layout yang digunakan cukup baik dan mudah dimengerti. Aspek tampilan yang sesuai dengan Process 
genre - based approach. Bentuk dan ukuran font juga dianggap cukup sesuai dengan perkembangan mahasiswa. Jika dilihat dari kategori validasi bahwa skor validasi adalah 75.4 handout dapat dikategorikan B. Ini berarti bahwa handout dapat digunakan dengan melakukan sedikit revisi. Tahap validasi ahli cukup dilakukan hanya sekali karena tidak ditemukan kesalahan fatal dalam desain draft.

Validator juga memberikan beberapa catatan untuk perbaikan handout yakni indikator belum mewakili indicator kegiatan menulis karena tidak ada indikator yang mengarahkan mahasiswa untuk menghasilkan struktur teks. Dalam pemodelan dan memperkuat bagian penilai yang berpikir bahwa materi pengajaran pada pemodelan dan penguatan bagian harus diubah karena kegiatan pada bagian-bagian tersebut tidak sesuai dengan aktivitas menulis. Kegiatan dekonstruksi, untuk membangun teks belum ada sehingga perlu dikembangkan.

Berdasarkan hasil evaluasi dan saran dari penilai, beberapa revisi dilakukan pada handout. Peneliti menganalisis teks yang digunakan dan membuatnya menjadi bervariasi untuk menghindari bahan pengajaran yang monoton. Instruksi yang diberikan juga perlu sedikit direvisi guna lebih mengacu pada langkah-langkah Proses Genre - Pendekatan Berbasis. Penggunaan bahasa juga sedikit direvisi dengan memperhatikan struktur gramatikal bahasa Inggris. Sejumlah revisi juga dilakukan dalam aspek penampilan seperti font yang digunakan, ruang kosong tersedia sebagai karakteristik handout, beberapa gambar menarik dan beberapa tabel berwarna.

Berdasarkan hasil validasi yang telah dilakukan ahli bisa disimpulkan bahwa validasi kedua tidak perlu dilakukan dikarenakan produk sudah bernilai 75.4 dengan kategori B yang berarti bahwa produk bisa langsung digunakan dengan sedikit revisi.

\section{KESIMPULAN}

Berdasarkan hasil validasi yang telah dilakukan ahli bisa disimpulkan bahwa validasi kedua tidak perlu dilakukan dikarenakan produk sudah bernilai 75.4 dengan kategori B yang berarti bahwa produk bisa langsung digunakan dengan sedikit revisi.

\section{UCAPAN TERIMA KASIH}

Terbitnya tulisan ini tidak terlepas dari bantuan berbagai pihak, untuk itu penulis ucapkan terima kasih yang sebesar-basarnya kepada Pihak STKIP PGRI Sumatera Barat khususnya pengelola jurnal Pelangi yang telah memberikan kesempatan kepada penulis untuk menulis dijurnal Pelangi.Selanjutnya penulis juga berterima kasih kepada para penyumbang sumber insirasi yang telah memerikan inspirasi bagi penulis untuk mengutip atau menggunakan tulisannya sebagai bahan referensi.

\section{DAFTAR RUJUKAN}

Badger, R and White, G. 2000. A Process Genre Approach to Teaching Writing. ELT Journal, Volume 54, Issue 2: 153-160.

Boardman, Cynthia and Frydenberg, Jia. 2002. Writing to Communicative: Paragraphs and Essays $2^{\text {nd }}$ Edition. Longman: Pearson Education, Inc.

Departement Pendidikan Nasional. 2008. Memilih Bahan Ajar. Jakarta : Depdiknas. 
Dikmenjur. 2008. Panduan Pengembangan Bahan Ajar. Jakarta: Dikmenjur.

Gay, L.5 R. 2009. Educational Research: Competencies for Analysis and Ap6plication. Columbus: Merril Publishing Company.

Gebhard, Jerry G. 1996. Teaching English as A Foreign Language: A Teacher Self-Development and Methodology Guide. Michigan: The University of Michigan Press.

Kim, Miyoun. 2007. Genre-Based Approach to Teaching Writing, (On line), web.1.hpu.edu/images/graduates studies/TESL_WPS/07.KimGenre-a17238.pdf

Kim, Yanghee and Kim Jiyoung.2005. Teaching Korean University Writing Class: Balancing the Process and the Genre approach. Asian EFL Journal(on line), http://www.asian-efljournal.com/june_05_yk\&jk.php

Linse, Caroline. T. 2005. Practical English language young Learners. New York: McGraw - Hill Companies.

Riduwan. 2005. Belajar Mudah Penelitian Untuk Dosen, Karyawan dan Peneliti Pemula. Bandung : Alphabeta.

Slamet. 2003. Belajar dan Faktor-faktor yang Mempengaruhinya. Jakarta: PT Rineka Cipta.

Soelistia, Umar. 2001. Pengembangan Bahan Ajar. Retrieved from http://pustaka.ut.ac.id/puslata/onli ne.php?menu=bmpshort_detail2\&I $\mathrm{D}=31$ at $\mathrm{Jan} 5^{\text {th }}, 2010$.
Sugiyono, 2008. Metode Penelitian Kuantitatif, Kualitatif dan $R \& D$. Jakarta : Alfhabeta.

Tim Puslitjaknov. 2008. Metode Penelitian Pengembangan. Jakarta: Depdiknas.

Yan, Guo. 2005. A Process Genre Model for Teaching Writing. English Teaching Forum Volume, 43; Number 3. 